\title{
Prevalence of Clonorchis sinensis Infection among Residents along 5 Major Rivers in the Republic of Korea
}

\author{
Young-II Jeong ${ }^{\dagger}$, Hee-Eun Shin†, Sang-Eun Lee, Hyeng-II Cheun, Jung-Won Ju, Jung-Yeon Kim, Mi Yeoun Park, \\ Shin-Hyeong Cho*
}

Division of Malaria and Parasite Diseases, Korea National Institute of Health, Korea Centers for Disease Control and Prevention,

Cheongju (Osong) 28159, Korea

\begin{abstract}
Clonorchis sinensis is currently the most important parasite affecting public health problems in the Republic of Korea. We investigated the prevalence of $C$. sinensis infection among residents living along 5 major rivers in Korea. A total of 42,562 individual stool samples were collected from 37 localities and examined using the formalin-ether sedimentation technique. Helminth eggs were detected in 4,052 (9.5\%) residents and 3,586 (8.4\%) were infected with $C$. sinensis. The egg positive rate of $C$. sinensis in Nakdong, Seomjin, Geum, Yeongsan, and Han River was $11.7 \%, 9.9 \%, 6.5 \%, 3.1 \%$, and $1.0 \%$, respectively. The overall prevalence of clonorchiasis by sex was $11.2 \%$ in males and $6.2 \%$ in females. The age-prevalence was the highest in the 50-59 years band. It has been reconfirmed that the endemicity of clonorchiasis is higher in southern areas of Korea, especially along Nakdong and Seomjin Rivers. A combination of continuous control programs with health education initiatives is urgently required in these highly endemic areas of clonorchiasis in Korea.
\end{abstract}

Key words: Clonorchis sinensis, clonorchiasis, prevalence, riverside resident, 5 major rivers, Korea

Until the 1970s in the Republic of Korea (Korea), parasitic infections with soil-transmitted intestinal nematodes, such as Ascaris lumbricoides, Trichuris trichiura, and hookworms, were highly prevalent $[1,2]$. Since 1971 , nationwide surveys have been conducted every 5-7 years in order to estimate the infection status of intestinal helminth parasites until 2004 [3]. In the first 1971 survey, the overall prevalence was $84.3 \%$, and by 2004, the rate had dramatically decreased to $3.7 \%$. The rapid decrease in the overall prevalence of intestinal parasites over the past several decades has been attributed mainly to nationwide control programs and health education initiatives undertaken by the Korean government along with improvements in the living conditions and quality of life in Korea [4]. Despite the remarkable decrease of soil-transmitted nematode infections, the prevalence of fish-borne trematode infections such as clonorchiasis and metagonimiasis has still remained to be relatively high [5].

The liver fluke, C. sinensis, is the most important helminth in Korea these days, and clonorchiasis has been known as the

- Received 21 July 2015, revised 12 January 2016, accepted 20 January 2016.

*Corresponding author (tell74@naver.com)

${ }^{\dagger}$ These authors contributed equally to this work.

(c) 2016, Korean Society for Parasitology and Tropical Medicine

This is an Open Access article distributed under the terms of the Creative Commons Attribution Non-Commercial License (http://creativecommons.org/licenses/by-nc/3.0) which permits unrestricted non-commercial use, distribution, and reproduction in any

medium, provided the original work is properly cited. cause of biliary pathogenesis, i.e., inflammation, dilatation, wall thickening, mucosal hyperplasia, liver cirrhosis, and even cholangiocarcinoma [6-8]. Among human diseases caused by parasites, clonorchiasis is ranked at the first due to its social, economic, and public health impacts in Korea. Clonorchiasis is endemic in most of the major river basins of Korea [9]. In 1981, the egg positive rates of people living in those river basins differed considerably; $40.2 \%$ in Nakdong River, $30.8 \%$ in Yeongsan River, 17.3\% in Seomjin River, 15.7\% in Han River, $15.9 \%$ in Tamjin River, and $12.0 \%$ in Geum River [10]. However, in 2007, the positive rates of C. sinensis in Nakdong, Seomjin, Yeongsan, Geum, and Han Rivers were 12.2\%, 9.5\%, $3.3 \%, 3.0 \%$, and $1.0 \%$, respectively [11]. Although the infection rates of C. sinensis in these major rivers decreased considerably over the past 20 years, clonorchiasis continues to persist and is currently considered as the most important helminthiasis in Korea.

In this study, we investigated the infection status of populations identified to be at risk of clonorchiasis, notably among residents living along 5 major rivers. The surveyed areas consisted of 37 counties, which are located in the vicinity of the Han, Geum, Yeongsan, Seomjin, and Nakdong Rivers, Korea. A total of 42,562 fecal specimens were collected from residents of these regions using a random household sampling method from February to November 2008 (Fig. 1). Stool specimens in 

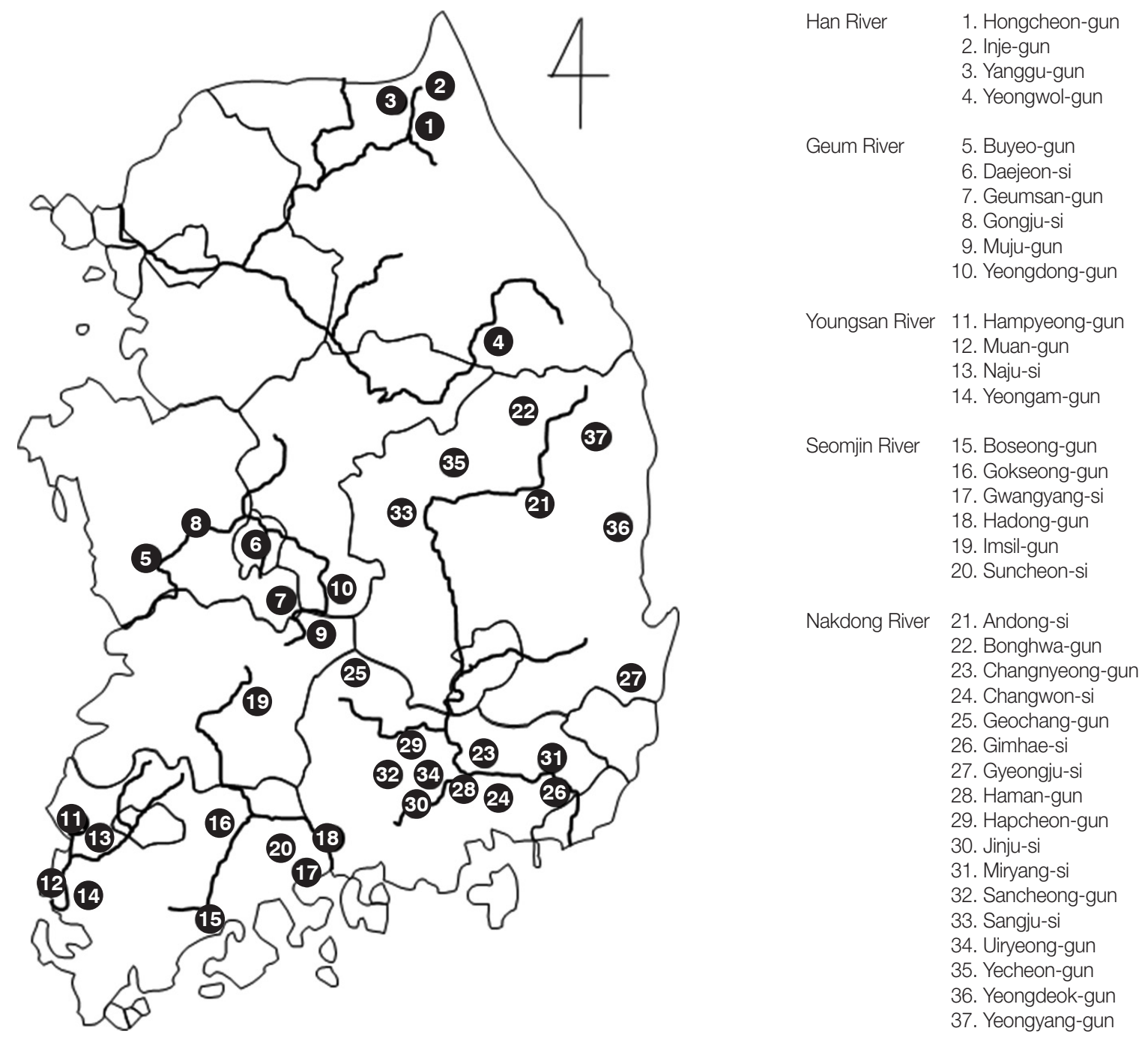

Fig. 1. Surveyed areas along 5 major rivers, the Republic of Korea.

Table 1. Positive rates of parasite eggs by fecal examination in residents along 5 major rivers

\begin{tabular}{lc}
\hline Parasite species & No. positive cases (\%) \\
\hline Overall intestinal parasites & $4,052(9.5)$ \\
Helminths & \\
Clonorchis sinensis & $3,586(8.4)$ \\
Metagonimus spp. & $411(1.0)$ \\
Trichuris trichiura & $63(0.1)$ \\
Echinostoma spp. & $12(0.03)$ \\
Hookworm & $5(0.01)$ \\
Ascaris lumbricoides & $4(0.01)$ \\
Gymnophalloides seoi & $4(0.01)$ \\
Strongyloides stercolalis & $4(0.01)$ \\
Trichostrongylus orientalis & $1(0.002)$ \\
Diphyllobothrium sp. & $1(0.002)$ \\
Co-infection & \\
C. sinensis+Metagonimus spp. & $78(0.18)$ \\
C. sinensis+Echinostoma spp. & $7(0.02)$ \\
C. sinensis+T. trichiura & $5(0.01)$ \\
\hline
\end{tabular}

plastic containers (1/person) collected in individual survey areas were transferred to the laboratory of National Institute of Health, and then examined by means of the formalin-ether sedimentation technique. Microscopic examinations were performed twice by well-trained technicians. The egg positive rate was estimated by arithmetic means. The egg positive individuals were treated with either praziquantel or other appropriate anti-parasitic drugs at the end of the study.

More than 10 species of helminth eggs were detected in 4,052 (9.5\%) stool samples (Table 1). Eggs of C. sinensis were found in 3,586 (8.4\%) fecal specimens of residents. The prevalence of clonorchiasis was highest in residents of Nakdong River (11.7\%), followed by Seomjin River (9.9\%), Geum River (6.5\%), Yeongsan River (3.1\%), and Han River (1.0\%). Especially, Gyeongju-si (city) had the highest rate of $25.9 \%$, fol- 
Table 2. Prevalence of overall intestinal parasites and $C$. sinensisaccording to localities and river basins

\begin{tabular}{|c|c|c|c|c|c|}
\hline River basins & Locality & No. of examination & No. of positive (\%) & No. of cumulative positive (\%) & C. sinensis (\%) \\
\hline Han river & $\begin{array}{l}\text { Hongcheon-gun } \\
\text { Inje-gun } \\
\text { Yanggu-gun } \\
\text { Yeongwol-gun } \\
\text { Subtotal }\end{array}$ & $\begin{array}{l}1,016 \\
1,265 \\
1,025 \\
1,349 \\
4,655\end{array}$ & $\begin{aligned} 22 & (2.2) \\
15 & (1.2) \\
9 & (0.9) \\
35 & (2.6) \\
81 & (1.7)\end{aligned}$ & $\begin{aligned} 22 & (2.2) \\
15 & (1.2) \\
9 & (0.9) \\
37 & (2.7) \\
83 & (1.8)\end{aligned}$ & $\begin{aligned} 16 & (1.6) \\
8 & (0.6) \\
4 & (0.4) \\
19 & (1.4) \\
47 & (1.0)\end{aligned}$ \\
\hline Geum river & $\begin{array}{l}\text { Buyeo-gun } \\
\text { Daejeon-si } \\
\text { Geumsan-gun } \\
\text { Gongju-si } \\
\text { Muju-gun } \\
\text { Yeongdong-gun } \\
\text { Subtotal }\end{array}$ & $\begin{array}{r}1,433 \\
1,075 \\
1,209 \\
1,016 \\
1,708 \\
287 \\
6,728\end{array}$ & $\begin{array}{rr}47 & (3.3) \\
42 & (3.9) \\
61 & (5.0) \\
48 & (4.7) \\
204 & (11.9) \\
74 & (25.8) \\
476 & (7.1)\end{array}$ & $\begin{array}{rr}47 & (3.3) \\
42 & (3.9) \\
62 & (5.1) \\
48 & (4.7) \\
208 & (12.2) \\
78 & (27.2) \\
485 & (7.2)\end{array}$ & $\begin{array}{rr}40 & (2.8) \\
40 & (3.7) \\
53 & (4.4) \\
47 & (4.6) \\
190 & (11.1) \\
68 & (23.7) \\
438 & (6.5)\end{array}$ \\
\hline Yeongsan river & $\begin{array}{l}\text { Hampyeong-gun } \\
\text { Muan-gun } \\
\text { Naju-si } \\
\text { Yeongam-gun } \\
\text { Subtotal }\end{array}$ & $\begin{array}{l}1,144 \\
1,267 \\
1,271 \\
1,041 \\
4,723\end{array}$ & $\begin{aligned} 47 & (4.1) \\
83 & (6.6) \\
54 & (4.2) \\
48 & (4.6) \\
232 & (4.9)\end{aligned}$ & $\begin{aligned} 52 & (4.5) \\
83 & (6.6) \\
54 & (4.2) \\
48 & (4.6) \\
237 & (5.0)\end{aligned}$ & $\begin{array}{rr}29 & (2.5) \\
32 & (2.5) \\
45 & (3.5) \\
40 & (3.8) \\
146 & (3.1)\end{array}$ \\
\hline Seomjin river & $\begin{array}{l}\text { Boseong-gun } \\
\text { Gokseong-gun } \\
\text { Gwangyang-si } \\
\text { Hadong-gun } \\
\text { Imsil-gun } \\
\text { Suncheon-si } \\
\text { Subtotal }\end{array}$ & $\begin{array}{l}1,200 \\
1,650 \\
1,394 \\
1,065 \\
1,074 \\
1,162 \\
7,545\end{array}$ & $\begin{array}{r}141(11.8) \\
169(10.2) \\
148(10.6) \\
281(26.4) \\
66(6.1) \\
136(11.7) \\
941(12.5)\end{array}$ & $\begin{array}{r}148(12.3) \\
178(10.8) \\
149(10.7) \\
306(28.7) \\
68(6.3) \\
144(12.4) \\
993(13.2)\end{array}$ & $\begin{array}{rr}123 & (10.3) \\
137 & (8.3) \\
86 & (6.2) \\
233 & (21.9) \\
57 & (5.3) \\
112 & (9.6) \\
748 & (9.9)\end{array}$ \\
\hline Nakdong river & $\begin{array}{l}\text { Andong-si } \\
\text { Bonghwa-gun } \\
\text { Changnyeong-gun } \\
\text { Changwon-si } \\
\text { Geochang-gun } \\
\text { Gimhae-si } \\
\text { Gyeongju-si } \\
\text { Haman-gun } \\
\text { Hapcheon-gun } \\
\text { Jinju-si } \\
\text { Miryang-si } \\
\text { Sancheong-gun } \\
\text { Sangju-si } \\
\text { Uiryeong-gun } \\
\text { Yecheon-gun } \\
\text { Yeongdeok-gun } \\
\text { Yeongyang-gun } \\
\text { Subtotal }\end{array}$ & $\begin{array}{r}1,932 \\
936 \\
1,044 \\
851 \\
1,256 \\
184 \\
710 \\
1,142 \\
1,142 \\
1,020 \\
1,603 \\
1,365 \\
1,067 \\
955 \\
1,314 \\
1,253 \\
1,137 \\
18,911\end{array}$ & $\begin{array}{rr}258(13.4) \\
20(2.1) \\
147(14.1) \\
58(6.8) \\
63(5.0) \\
6(3.3) \\
185(26.1) \\
121(10.6) \\
184(16.1) \\
137(13.4) \\
291(18.2) \\
226(16.6) \\
91(8.5) \\
115(12.0) \\
152(11.6) \\
154(12.3) \\
114(10.0) \\
2,322(12.3)\end{array}$ & $\begin{array}{rr}261(13.5) \\
20(2.1) \\
149(14.3) \\
58(6.8) \\
64(5.1) \\
6(3.3) \\
185(26.1) \\
122(10.7) \\
189(16.5) \\
140(13.7) \\
294(18.3) \\
228(16.7) \\
92(8.6) \\
115(12.0) \\
152(11.6) \\
162(12.9) \\
114(10.0) \\
2,351(12.4)\end{array}$ & $\begin{array}{rr}242 & (12.5) \\
16 & (1.7) \\
141 & (13.5) \\
56 & (6.6) \\
61 & (4.9) \\
6 & (3.3) \\
184(25.9) \\
111(9.7) \\
180(15.8) \\
134(13.1) \\
268(16.7) \\
222(16.3) \\
86(8.1) \\
112(11.7) \\
151(11.5) \\
125(10.0) \\
112(9.9) \\
2,207(11.7)\end{array}$ \\
\hline Total & & 42,562 & $4,052 \quad(9.5)$ & $4,149 \quad(9.7)$ & $3,586(8.4)$ \\
\hline
\end{tabular}

Table 3. Positive rate of $C$. sinensis according to gender and river basins

\begin{tabular}{lrrr}
\hline \multirow{2}{*}{ River basins } & \multicolumn{3}{c}{ No. of positive / No. examined (\%) } \\
\cline { 2 - 4 } & \multicolumn{1}{c}{ Male } & \multicolumn{1}{c}{ Female } & Total \\
\hline Han river & $32 / 2,518(1.3)$ & $15 / 2,137(0.7)$ & $47 / 4,655(1.0)$ \\
Geum river & $307 / 3,076(10.0)$ & $131 / 3,628(3.6)$ & $438 / 6,728(6.5)$ \\
Yeongsan river & $84 / 1,915(4.4)$ & $62 / 2,808(2.2)$ & $146 / 4,723(3.1)$ \\
Seomjin river & $422 / 3,221(13.1)$ & $326 / 4,324(7.5)$ & $748 / 7,545(9.9)$ \\
Nakdong river & $1,306 / 8,555(15.3)$ & $901 / 10,327(8.7)$ & $2,207 / 18,911(11.7)$ \\
Total & $2,151 / 19,285(11.2)$ & $1,435 / 23,224(6.2)$ & $3,586 / 42,562(8.4)$ \\
\hline
\end{tabular}

lowed by Hadong-gun of $21.9 \%$, which were located in the mid- or downstream of Nakdong and Seomjin Rivers, respec- tively. Egg positive rates by surveyed areas are shown in Table 2.

The overall prevalence of clonorchiasis by sex was $11.2 \%$ in 
Table 4. Prevalence of $C$. sinensis eggs according to age groups and river basins

\begin{tabular}{lccccccccc}
\hline & \multicolumn{7}{c}{ No. of positive / No. of examined (\%) } \\
\cline { 2 - 9 } River basins & Total & $1-19$ & $20-29$ & $30-39$ & $40-49$ & $50-59$ & $60-69$ & $70-79$ & $80-$ \\
\hline Han river & $47 / 4,655$ & $1 / 242$ & $7 / 719$ & $3 / 327$ & $11 / 652$ & $17 / 965$ & $4 / 917$ & $4 / 706$ & $0 / 115$ \\
& $(1.0)$ & $(0.4)$ & $(1.0)$ & $(0.9)$ & $(1.7)$ & $(1.8)$ & $(0.4)$ & $(0.6)$ & $(0.0)$ \\
Geum river & $438 / 6,728$ & $2 / 302$ & $5 / 163$ & $7 / 342$ & $48 / 738$ & $127 / 1,330$ & $122 / 1,746$ & $107 / 1,638$ & $15 / 390$ \\
& $(6.5)$ & $(0.7)$ & $(3.1)$ & $(2.0)$ & $(6.5)$ & $(9.5)$ & $(7.0)$ & $(6.5)$ & $(3.8)$ \\
Yeongsan river & $146 / 4,723$ & $0 / 56$ & $0 / 56$ & $3 / 103$ & $18 / 378$ & $37 / 893$ & $48 / 1,531$ & $35 / 1,428$ & $4 / 261$ \\
& $(3.1)$ & $(0.0)$ & $(0.0)$ & $(2.9)$ & $(4.8)$ & $(4.1)$ & $(3.1)$ & $(2.5)$ & $(1.5)$ \\
Seomjin river & $748 / 7,545$ & $6 / 225$ & $11 / 116$ & $29 / 276$ & $77 / 642$ & $152 / 1,097$ & $203 / 2,073$ & $187 / 2,265$ & $34 / 626$ \\
& $(9.9)$ & $(2.7)$ & $(9.5)$ & $(10.5)$ & $(12.0)$ & $(13.9)$ & $(9.8)$ & $(8.3)$ & $(5.4)$ \\
Nakdong river & $2,207 / 18,911$ & $3 / 377$ & $6 / 235$ & $49 / 558$ & $224 / 1,815$ & $534 / 3,773$ & $666 / 5,523$ & $517 / 4,880$ & $69 / 938$ \\
& $(11.7)$ & $(0.8)$ & $(2.6)$ & $(8.8)$ & $(12.3)$ & $(14.2)$ & $(12.1)$ & $(10.6)$ & $(7.4)$ \\
Total & $3,586 / 42,562$ & $12 / 1,202$ & $29 / 1,289$ & $91 / 1,606$ & $378 / 4,225$ & $867 / 8,058$ & $1,043 / 11,790$ & $850 / 10,917$ & $122 / 2,330$ \\
& $(8.4)$ & $(1.0)$ & $(2.2)$ & $(5.7)$ & $(8.9)$ & $(10.8)$ & $(8.8)$ & $(7.8)$ & $(5.2)$ \\
\hline
\end{tabular}

males and 6.2\% in females (Table 3). The egg positive rate by age group was highest in the 50-59 age band, followed by the forties $(8.9 \%)$, sixties $(8.8 \%)$, seventies $(7.8 \%)$, thirties $(5.7 \%)$, over 80 (5.2\%), twenties (2.2\%), and below 19 (1.0\%) (Table 4$)$.

The present study provided the prevalence of $C$. sinensis infection among residents living along 5 major rivers of Korea and confirmed the high endemicity of $C$. sinensis infection in southern localities. Although the prevalence of clonorchiasis along the major rivers appears to decline over the past decade, we identified that Nakdong and Seomjin Rivers are still highly endemic regions in common with previous studies; a national survey undertaken in 1981 reported that the egg positive rates of people living along these major river basins were $40.2 \%$ in Nakdong River, 30.8\% in Yeongsan River, 17.3\% in Seomjin River, $15.7 \%$ in Han River, $15.9 \%$ in Tamjin River, and 12.0\% in Geum River [10]. Also, in 2006, the egg positive rates of $C$. sinensis observed in the river basins of Nakdong, Seomjin, Yeongsan, and Geum were 17.1\%, 11.2\%, 5.5\%, and 4.6\%, respectively [9]. In addition, our results showed that the positive rates of overall intestinal parasites and $C$. sinensis in residents along 5 major rivers was $9.5 \%$ and $8.4 \%$, respectively. The $9.5 \%$ prevalence of overall intestinal parasites is 2-fold higher than the national intestinal helminth prevalence of $3.7 \%$ in 2004 [3].

The infection status of $C$. sinensis according to age groups appears to be a typical pattern for $C$. sinensis infection, reaching a peak at the age groups of 40-49 and 50-59 years. These results suggest that the eating habit of raw fishes containing $C$. sinensis metacercariae is a deeply rooted traditional custom among residents living in rural and riverside areas. As well, the higher prevalence in males than in females may be caused by frequent alcohol consumption and raw freshwater fish intake with increasing activities such as fishing that are mostly carried out by men.

While not conceptually new, our results provided the basic data and important information regarding the prevalence of clonorchiasis in high risk regions in Korea and are valuable for providing control strategies and medication of clonorchiasis patients in these areas.

\section{ACKNOWLEDGMENT}

This study was supported by parasitic disease surveillance and control program of the National Institute of Health, Ministry of Health and Welfare, Republic of Korea (NIH-48004847-311).

\section{CONFLICT OF INTEREST}

We have no conflict of interest related to this work.

\section{REFERENCES}

1. Seo BS, Rim HJ, Loh IK, Lee SH, Cho SY, Park SC, Bae JW, Kim JH, Lee JS, Koo BY, Kim KS. Study on the status of helminthic infections in Koreans. Korean J Parasitol 1969; 7: 53-70.

2. Kim CH, Park CH, Kim HJ, Chun HB, Min HK, Koh TY, Soh CT. Prevalence of intestinal parasites in Korea. Korean J Parasitol 1971; 9: 25-38. 
3. Kim TS, Cho SH, Huh S, Kong Y, Sohn WM, Hwang SS, Chai JY, Lee SH, Park YK, Oh DK, Lee JK. A nationwide survey on the prevalence of intestinal parasitic infections in the Republic of Korea, 2004. Korean J Parasitol 2009; 47: 37-47.

4. Hong ST, Chai JY, Choi MH, Huh S, Rim HJ, Lee SH. A successful experience of soil-transmitted helminth control in the Republic of Korea. Korean J Parasitol 2006; 44: 177-185.

5. Shin EH, Guk SM, Kim HJ, Lee SH, Chai JY. Trends in parasitic diseases in the Republic of Korea. Trends Parasitol 2008; 24: 143-150.

6. Hong ST, Fang Y. Clonorchis sinensis and clonorchiasis, an update. Parasitol Int 2012; 61: 17-24.

7. Shin HR, Oh JK, Masuyer E, Curado MP, Bouvard V, Fang YY, Wiangnon S, Sripa B, Hong ST. Epidemiology of cholangiocarcinoma: an update focusing on risk factors. Cancer Sci 2010; 101:
579-585.

8. Choi BI, Han JK, Hong ST, Lee KH. Clonorchiasis and cholangiocarcinoma: etiologic relationship and imaging diagnosis. Clin Microbiol Rev 2004; 17: 540-552.

9. Cho SH, Lee KY, Lee BC, Cho PY, Cheun HI, Hong ST, Sohn WM, Kim TS. Prevalence of clonorchiasis in southern endemic areas of Korea in 2006. Korean J Parasitol 2008; 46: 133-137.

10. Seo BS, Lee SH, Cho SY, Chai JY, Hong ST, Han IS, Sohn JS, Cho BH, Ahn SR, Lee SK, Chung SC, Kang KS, Shim HS, Hwang IS. An epidemiologic study on clonorchiasis and metagonimiasis in riverside areas in Korea. Korean J Parasitol 1981; 19: 137-150.

11. Kim HK, Cheun HI, Cheun BS, Lee KY, Kim TS, Lee SE, Lee WJ, Cho SH. Prevalence of Clonorchis sinensis infections along the five major rivers in Republic of Korea, 2007. Osong Public Health Res Perspect 2010; 1: 43-49. 